\title{
The Interaction Between Angiotensin Converting Enzyme Inhibitor (Captopril) and Heat Stress in The Male Albino rats. 2-Tissue Analysis
}

\author{
Eman G.E. Helal ${ }^{1}$, Samir A.M. Zaahkouk ${ }^{2}$, \\ Talaat E.I. Abd-Rabo ${ }^{3}$ and Somaia Z.A. Rashed ${ }^{4}$. \\ ${ }^{1}$ Al-Azhar University for girls, Faculty of Science, Zoology Department \\ ${ }^{2}$ Al-Azhar University, Faculty of Science, Zoology Department \\ ${ }^{3}$ Tanta University, Faculty of Science, Zoology Department
}

\begin{abstract}
Daily exposure to heat stress causes sustained elevation of blood pressure in rats. It is known that the renin-angiotensin system is activated during episodes of behavioral stress, and the purpose of this work was to assess the action of captopril in the development of stress induced hypertension in rats.

Animals were divided into four groups. The first group served as a control, while the other groups were subjected to heat stress of $40^{\circ} \mathrm{C}$ and high hamidity of $80 \%$ for 10 successive days. The second group was served as heat stress, while the third and the fourth groups were received low and high doses of captopril $(0.7 \& 1.4 \mathrm{mg} / \mathrm{kg}$. b.wt., respectively). After 10 days of treatment, half of animals from each group were decapitated and brain, liver, muscle, heart and kidney were separated and analysed. The other half of animals were left for another 10 days without any additional treatment for recovery.The results revealed a significant decrease in total protein of liver, heart, kidney, total lipids of heart, muscle and brain and total cholesterol of liver. On the other hand, insignificant change was noticed in muscle and brain total protein. Similarly, AST and ALT activities were also within the normal values for all the organs examined.Results exhibited that renin-angiotensin system may be important in the development of stress-induced hypertension in rats.
\end{abstract}

\section{INTRODUCTION}

Hypertension has become a relatively common problem in recent years and it is often of long duration and refractory to standard antihype rtensive therapy. Epidemiologic studies indicate that the risks of damage to kidney, heart, and brain are directly related to the extent of blood pressure elevation. Even mild hypertension in young or middle-aged adults increases the risk of eventual and organ damage. The risk and therfore the urgency of instituting the rapidincrease in proportion to the

magnitude of blood pressure elevation. In fact, hyperten -sion is usually a symptomatic until over end organ damage is imminent or has already occurred. Angiotensin converting enzyme (ACE) inhibitors is popular in the treatment of hypertension. Captopril is one of them and it has been shown to be effective in lowering blood pressure in hypertensive patients. Laderle (1985) considered that captopril may have 
theoretically some advantages as compared with other antihypertensive drugs, which may have adverse effects on the patients. Zhang and $\mathrm{Xu}$ (1994) stated that captopril signific -antly improved the cardiac function recovery and prevented the ischemia and reperfusion injury in the hypertrophied heart.

Captopril therapy has been reported to be associated with renal failure, hemolytic anaemia and skin rash (Luderer et al., 1981). Also, captopril lowered serum creatinine in rats (Vargas et al., 1994) and had a stimulatory effect on arachidonic acid metabolism, in addition to its free radical scavenging effect (Gulluoglu et $a l .$, 1996). Cutaneous reaction and renal dysfunction have also been demonstrated by Smit et al. (1984) and Swales (1995), respectively. Ganapathy et al. (1985) observed an inhibition of hepatic prolibase in captopril-treated rat and human. Sakr (1995), stated that captopril caused renal and hepatic lesions. On the other hand, Zhang and $\mathrm{Xu}$ (1994) found that captopril prevented the schema and repair fusion injury in the hypertrophied heart according to inhibition of the cardiac renin-angiotensin system. Also, captopril decreased the mobility of rats in the open field (Vernigora et al., 1996) and affected the behavior of the home cage emergence rats and open field escape rats (Prickaerts et al., 1996).

Coste et al. (1995) found that ten days of air-jet stress caused a significant elevation of blood pressure in borderline hypertensive rats exposed to air-jet stress without receiving captopril but not in animals given captopril concurrently with air-jet stress. So, they concluded that the renin-angiotensin system may be important in the development of stressinduced hypertension in the borderline hypertensive rats.

It is known that the reninangiotensin system is activated during episodes of behavioral stress. In a previous study, we examined the effects of angiotensin converting enzyme (ACE) inhibitors and heat stress on some haematologial and biochemical parameters in the serum of male albino rats. The purpose of the present study was planned to assess the effect of both captopril and heat stress on the physiological function of some vital organs as liver, heart, kidney, brain and muscle.

\section{MATERIAL AND METHODS}

Forty male albino rats weighed about $(120-150 \mathrm{~g})$ were used in this experiment. The animals were housed in suitable cages inside a thermostatic chamber, in which the room temperature was controlled by thermestors and the relative humidity was measured by thermohygrometer.

They were acclimatized for 10 days before the beginning of the experiment, and fed ad libitum with a commercial diet. They were allocat ed into four equal groups. One group acted as a control, others were put in home cage's temperature at $40^{\circ} \mathrm{C}$ and humidity $80 \%$. One of these groups was acting as a heat stress control, the other two groups had oral treatment with a solution of an active

gradient of captopril in distilled water (captopril, $99.98 \%$ or dry, $0.11 \%$ water, Epico) at 0.7 and $1.4 \mathrm{mg} / \mathrm{kg} . b . w t$ for the third and fourth groups, respectively. Half of the group was decapitated after 10 days of treatment while the other half was kept 10 days after the last dosing without any additional treatment in order to follow up any recovery signs. 


\section{The Interaction Between Angiotensin Converting}

At the end of each period, animals were weighted then decapitated and rapidly dissected and selected organs (heart, liver, brain, kidney and muscle) were taken, then cleaned and weighted, and pieces of each were weighted put in appropriate amount of $30 \%$ potassi -um hydroxide for total protein determination, in concentrated sulph -oric acid for total lipids, or in saline and hemoginized for determination of cholesterol and estimation of AST and ALT activities.

Total protein was estimated using Biuret method as described by Doumas (1975). Total lipids were determined using the method of Knight et al. (1972). In case of cholesterol level, it was measured according to the method of Jung and Parekh (1971). ALT and AST activities were demonstrated accor -ding to the method of Rabbo et al. (1963).

To compare the results of different experimental animal groups, the student " $t$ " test was used. Significant differences between the means of control and treated groups were considered only at $\mathrm{P}<0.05$ (Sokal and Rahif, 1981).

\section{RESULTS}

Table (1) \& figure (1) exhibited non significant change in percentage of organ/body weight ratio for all groups in both treated and recovery periods for each of liver, kidney, brain and testis organ.

On the other hand, the present study indicated significant elevation $(\mathrm{P} \leq 0.01)$ in percentage of heart weight/body weight ratio in (control + heat stress) group after treatment period (10 days), this ratio recorded significant decreased $(\mathrm{P} \leq 0.01)$ in both (heat stress + low dose captopril) and (heat stress + high dose captopril) group after treated period, the same results were noticed for percentage of spleen wt./body wt. ratio as shown in Table (1) and Figure (1).

It is clear that heat stress resulted in an initial reduction of liver total protein. This reduction was highly significant $(\mathrm{P}<0.01)$ till the end of the experiment except in the case of low dose treatment which recorded a significant decrease $(\mathrm{P}<0.05)$ after the recovery period (table 2 and figure 2 ).

After 10 days of treatment, all of rats treated with captopril showed a highly significant $(\mathrm{P}<0.01)$ decrease in heart protein. The group exposed to heat stress showed a significant $(\mathrm{P}<0.05)$ decrease till the end of the experiment. After the recovery period, low dose of captopril treated $(0.7 \mathrm{mg} / \mathrm{kg}$. b.ut $)$ showed a significant $(\mathrm{P}<0.05)$ decrease in heart protein, while the high dose groups was still higher $(\mathrm{P}<0.01)$.

However, highly significant decrease of kidney protein $(\mathrm{P}<0.01)$ was recorded after 10 days of treatment in all treated groups. After the recovery period rats exposed to heat stress or that treated with low dose of captopril showed insignificant change, while the grouptreated with a high dose was still significant $(\mathrm{P}<0.05)$.

However, all treated rats did not show appreciable changes both muscle and brain total protein as compared with their corresponding control group (table 2 and figure 2).

The obtained results presented in (table 3 and figure 3) indicated that the level of total skeletal muscle, heart and brain lipids showed a highly significant decrease $(\mathrm{P}<0.01)$ for both stress and all doses used of captopril throughout the experimental period. Similarly, a highly significant decrease $(\mathrm{P}<0.01)$ of the total liver lipids was recorded for heat stress and low dose of captopril $(0.7 \mathrm{mg} / \mathrm{kg}$. b.wt). While high dose of captopril showed insignificant change during the treated period 
followed by significant decrease $(\mathrm{P}<$ 0.05 ) after the

recovery period. On the other hand, total kidney lipids showed highly significant decrease for all treated groups after the treated period and lasted to the end of the experiment (except the group of heat stress which showed insignificant change after the recovery period).

Heat stress and captopril treatment of rats induced a signif -icant decrease $(\mathrm{P}<0.01)$ for the

level of cholesterol of liver after 10 days of treatment. This decrease lasted to the end of the experiment i.e. after 20 days (table 4 and figure 4). Furthermore, a high significant decrease $(\mathrm{P}<0.01)$ of heart choles -terol was recorded for heat stress and low dose $(0.7 \mathrm{mg} / \mathrm{kg}$. b.wt) treated groups after 10 days of treatment. While, high dose of captopril $(1.4 \mathrm{mg} / \mathrm{kg}$. b.wt) showed a significant decrease $(\mathrm{P}<0.05)$ of heart cholesterol.

After the recovery period, no significant changes was recorded for captopril treated groups. But, heat stress groups was till show a significant decrease $(\mathrm{P}<0.05)$. The same results were obtained for kidney cholesterol after the treated period, while insignificant changes were recorded for all treated groups after the recovery period. Concer -ning skeletal muscle and brain cholesterol highly significant decre -ase $(\mathrm{P}<0.01)$ were observed in all treated rats after the treated period. On the other hand, non significant change was recorded after the recovery period for captopril treated groups. While, heat stress group was still pronounced $(\mathrm{P}<0.01)$ as shown in (table 4 and figure 4 ).

The present study indicated that, AST and ALT activities (except ALT of liver) of male albino rats tended to increase in heat stress even if captopril was used (tables $5 \& 6$ and figures $5 \&$ $6)$. However, after the recovery period, the same results were noticed except that ALT

activity of liver were still lesser than that of the control groups.

Yet, it was still within the normal values for all groups after the treated period (10 days) or the recovery period in comparison with that of the control groups.

\section{DISCUSSION}

It is well known that heat stress in middle and old age is associated frequently with degenera -tive cardiovascular disease, particul -arly arteriosclerosis, hypertension and myocardial ische -mia (Ferguson and O'Brien, 1960). Also, Coste et al. (1995) stated that daily exposure to airjet-stress (AJS) caused sustained elevation of blood pressure in borderline hypertensive rats. Hypertension, congestive heart failure and myocardial infraction are common diseases. Most of these disorders necessitate drug treatment of long duration. Angiotensin-converting enzyme inhibitors are now the usual treatment for those disorders. Intensive antihypertensive therapy may be followed by functional impairment of many organ system (Kumar et al., 1976 and Cove et al., 1979).

Taguma et al. (1985) was the first to report that captopril treatment reduced heavy proteinuria in patients with advanced diabetic nephropathy. Since there were several studies have been carried out to evaluate the proteinuria-reducing or renal-protective effect of ACE inhibitors in patients with chronic renal failure or diabetic nephropathy (Marre et al., 1988, Bedogna et al., 1990; Heeg et al., 1987 and Parving et al., 1988), as well as in 


\section{The Interaction Between Angiotensin Converting}

animal models of chronic renal disease (Andrson et al., 1986; Zats et al., 1986 and Beukers et al., 1989). The present work revealed that the level of skelelal, liver and kidney proteins was lower than that of control rats after 10 days of heat stress and captopril admin istration and it lasted to the end of the experiment (20 days of treatment). This might result from tissue degradation or changes of cell permeability. This is in harmony with Helal and Zahkouk (1999) who recorded an increase in serum protein level after captopril. In support of this, the remarkable decrease of body weight recorded by Helal and Zahkouk (1999). The decrease of liver protein level throughout the experimental period, might be a result of cytotoxic effects of captopril especially to the liver.

In previous work, there was significantly increase of total serum protein for all treated groups. This was accompanied with a decrease of tissue proteins in all treated groups in the present study. It is clear that the increase of serum protein and the decrease of liver, heart and kidney protein resulted from tissue degradation of cell permeability. This is in harmony with the increased blood glucose level mostly through gluconeogensis and/or haemoconcentration. The decrease of tissue proteins could be a reflection to inhibition of DNA and/or RNA and hence protein synthesis. A decrease of nucleic acids, total protein of liver in birds (Saleh, 1990) and different mammals (El-Fiky et al., 1992 and Amer et al., 1994) has been reported.

The hazardous effect of heat stress may occure during prenatal growth and still unknown during postnatal growth (El-Sayed, and Kariem 1996). The bad effect of hyperthermia on tissues may be attributed to the inhibition of tissue protein synthesis as reported by Millan et al., (1979) or denaturation of protein which represents the main cause of cell death (Westra and Dewey, 1971 and Rosenbery et al., 1971).

In the present work, significant decrease of both total lipids and cholesterol was observed in different organs. In a previous study, Helal and Zhakhouk (1999) reported that captopril and heat stress induced significant decrease of ser -um total lipids accompanied by significant increase of serum cholest -erol. The decrease of tissue cholesterol levels correlated well with the proposed impairment of different organ function specially liver function. Several theories had been advanced to explain the reason of cholesterol lowering mechanisms, including the stimulation of cholest erol excretion into the intestine, stimulation the oxidation of cholesterol to bile salts, blocking the re-absorption of cholesterol from the gastrointestinal tract, preventing the re-absorption of bile, salts and inhibition of cholesterol synthesis (Levy, 1977).

The present study showed a decrease in ALT activity of liver which is a good sign of the disorder of liver function, and clear to the damage of liver tissues. These results are agreement with the findings of Helal and Zahkouk (1999). The effect of heat stress on the liver is in accordance with Saissy et al. (1996), who reported that exertional heat stroke can cause fulminant liver failure, resulting either from the direct effect of heat on the hepatic parenchyma, or from acute hepatic ischemia due to blood redistribution made worse by the hypersecretion of antidiuretic hormone, a potent portal vasoconstrictor, which occurs in the heat acclimated subject.

Also, Sort et al. (1996) recorded the first case of severe and recurrent 
liver impairment due to heat stroke. It was clear from this study that captopril has a limited effect on the different tissue organs, even after the recovery period.

In the present study, the significant increase in percentage of heart wt./body wt. ratio may be an adapted result to heat stress after treatment period, this was in agreement with. Hore (1975) who stated that, at higher temperatures the optimum fibre length is greater for the development of the maximum tension, moreover heat stress in middle and old age is associated frequently with degenerative cardiovascular disease, particularly arteriosclerosis, hypertension, myocardial ischemia \& myocardial infarction Ferguson and O'Brien (1960) Coste et al., (1995) and Helal and Zahkouk, (1999). Angiotensin converting enzyme (ACE) inhibitors are now the usual treatment for those disorders. Intensive antihypertensive therapy may be followed by functional impairment of many organ system (Kumar et al., 1976 and Cove et al., 1979).

The decrease in the percentage of heart wt./body wt. ratio in low and high dose captopril treatment was in agreement with the findings of several studies. (Urata et al., 1990; Urata et al., 1991 \& Kanazawa et al. 1995) they stated that captopril treatment attenuate the increase in heart weight./body

\section{REFERENCES}

Amer, T.A.; Ibrahim, H.A.; Badawy, M.E. and El-Sawi, M.R. (1994): Curocron toxicity on some rat liver fractions. 1-Nucleic acid metabolism and transaminases activity. J.Egypt. Ger. Soc. Zool., 14 (A): 123-141.

Anderson, S.; Rennke, H.G. and Brenner, B.M. (1986): Therapeutic weight ratio might partly explain the existence of angiotensin-forming pathways in the heart, which are not dependent on angiotensin converting enzyme, also Kimura et al., (1996) attributed the decrease in left ventricular weight/body weight ratio

in rats to the treatment with both taurine and enalapril (ACE inhibitor).

In the present work, the increase in percentage of spleen weight/body weight ratio after exposure to heat stress was noticed, this is in support with the findings of Ji-Y et al., (1995), Kimura et al., (1996), which attributed the increase in the ratio of spleen/body wt. in immunos-timulators mice to heat and cold stress. In contrast the treated animals with low and high doses of captopril exhibited a significant decrease in percentage of spleen weight/body weight ratio.

From the present data, it is well recommended to use captopril treatment in patients who suffered from hyperlipodemia, hyperpotei nemia and hypercholestrolemia as it's well know that findings on different stresses can't be necessarily extrapolated to other stresses. Because each stress factor act through its own mechanism and pathway. Nevertheless, the present findings would encourage similar undertaking on other stress, drugs and phyla. Thus should be of interest when considering possible application on other stresses and drugs at latter stage.

advantage of converting enzyme inhibitors in arresting progressive renal disease associated with systemic hypertension in the rat. J. Clin. Invest. 77: 1993-2000.

Bedogna, V.; Valvo, E.; Casagrande, P.; Braggo, P.; Fortanarosa, C.; Dalsanto, F., (1990): Effects of ACE 
inhibition in normotensive patients with chronic glomerular disease and normal reveal function. Kidney Int. 38: 101107.

Beukers, J.J.B.; Van Der Wal, A.; Hoede Maker, P.J. and weering, J.J. (1989): Converting enzyme inhibition and progressive glomerulosed erosis in the rat. Kidney Int., 32: 794-800.

Coste, S.C.; AI.Y.; Brooks, V.L.;

Mccarro N. P.A. and Hatton, D.C. (1995): Captopril and stress-induced hypertension in the border line hypertensive rat. J. Hypertens., 13 (12): 1391-1398.

Cove, D.H.; Seddon, M. and Fletcher, R.F. (1979): Blindness after treatment for malignant hypertension. Br. Med. J. 2:245.

Doumas, B.T. (1975): Colourimetric determination of total protein in serum or plasma. Clin. Chem. T2: 1159-1160.

El-Fiky, S.A.; Abdel-Aziz, K.B. and Abdel-Baset, S.A. (1992): Protective role of soya been against chromosomal and biochemical effects of carbaryl (seven) in male mice. J. Egypt. Soc. Toxicol., 9:29-31.

El-Sayed H.I.and Kariem S.A. (1996): Effect of hyperthermia on the development of some organs of breast feeding rats. J. Union. Arab. Biol., vol. 5(A) zoology 331-344.

Ferguson, M. and O'brien, M.M. (1960): Heat stroke in New York City. N.Y. St. 7. Med, 60-2531.

Ganapathy, V.; Pashley, S.J.; Roesel, R.A.; Pashley, D. H. and leibacl, F.H. (1985): Inhibition of rat and human prolidases by captopril. Biochem. Pharmacol., 34(8): 1287-1291.

Gulluoglu, B.M.; Aktan, A.O.; Yegen, C., Kurtel, H. and Yalin, F. (1996): Endothelin release in augmented with captopril in rat ischemia reperfusion injury of the liver. Res. Exp. Med. Berl. 196(4): 227-233.
Heeg, J.E.; De Jong, P.E.; Van Der Hem, G.K. and De Zeeuw, D. (1987): Reduction of proteinuria by angiotensin converting enzyme inhibition. Kidney Int. 32: 18-83.

Helal, E.G.E. and Zahkouk, S.A.M. (1999): The interaction between converting enzyme inhibitor captopril and heat stress in the male albino rats. 1-some hematological and biochemical parameters. Al-Azhar Bull. Sci. 10 (2): 1107-1122.

Hore, W. S. (1975): General and comparative physiology. Prentice-Hall, Inc, Englewood Cliffs, New Jersey, 330-44.

Ji-Y; Tao-L; Xu-Hl; Rao-MR (1995): Effects of taurine and enalapril on blood pressure, platelet aggregation and the regression of left ventricular hyperstrophy in two-kidney-one-clip renovascular hypertensive rats. YaoHsueh-Hsueh-Pao: 30(12): 886-890.

Jung, G.H. and Parekh, A.C. (1971): A new colour reaction for cholesterol assay. Clin. Acta, 35: 73-78.

Kanazawa M., Yoshida K., Fu. L.P. Obrara K., Saito T. and Abe K. (1995): Antihypertensive and reval-protective effects of losartan in streptozotocin diabetic rats. J. of Hypertension 13-97103.

Kimura-M; Suzuki-M; and Araki-S. (1996): Effects of immunos-timulators an involution of lynphoid organs in mice exposed to heat and cold stress. Jvet. Med. Sci. 58 (3) 255-7.

Knight, J.A., Anderson, S. and Rawle J.M. (1972): Chemical basis of the sulphophosphovanilin reaction for estimation total lipids. Clin. Chem. 18(3): 199-202.

Kumar, G.K.; Dastoor, F.C. and Robayo, J.R. (1976): Side effects of diazoxide, Jama, 235:275.

Laderle, R.M. (1985): Captopril and hydrochlorethiazide in the fixed 
combination multicenter trial. J. Cardiovas. pharmacol., 7: 505-569.

Levy, R.I. (1977): The effect of hypolipidemic drugs on plasma lipoproteins. Ann. Rev. Pharmacol, 17: 492.

Luderer, J.R.; Schoolwerth, A.C.; Sinicrope, R.A.; Halland, J.O.; LooKingbill, D.p. and Hayes, A.H. (1981): A cute renal failure, hemolytic anemia and skin rash associated with captopril therapy. Am. J. Med., 71: 493-496.

Marre, M.; Leblanc, H.; Swarez, L.; Guyenne, T.T.; Menard, J.; and Passa, P. (1988): Converting enzyme inhibition and kidney function in normotensive diabetic patients with persistent micro-albuminuria. B. MJ. 297:1092-1095.

Milan, N.; Murdock, L.L.; Bleier, R. and Siegel, F.L. (1979): Effect of acute hyperthermia an polyribosomes in vivo protein synthesis and ornithine decarboxylase activity in the neonatal rat brain. J. Neurochem, 32(2): 311-317.

Parving, H.H.; Hommel, E. and Smidth, U.M. (1988): Protection of kidney function and decrease in albuminuria by captopril in insulin dependent diabetes with nephropathy. B. MJ, 297: 1086-1091.

Prickaerts, J.; Raaijanakers, W. and Blokland, A. (1996): Effects of myocardial infarction and captopril therapy on anxiety-related behaviors in rat. Physiol. Behav. 60(1): 43-50.

Rabbo, E. (1963): Determination of serum lactic dehydrogenase by the tetrazolium salt method. Scand. J. Clin and Lab. Invest., 15 : 233-239.

Rosenberg, B.; Kemeny, G.; Switzer, R.C. and Hamilton, T.C. (1971): Quantitative evidence for protein denaturation as the cause of chemical death, Nature, 232: $\quad$ 471-473.

Saissy, J.M.; Amanza, L.; Samuel, D. and pats, B. (1996): Liver transplantation after exertion-induced heat stroke associated with fulminant liver failure. Presse-Med. 25(21): 977979.

Sakr, A.A. (1995): Renal and hepatic lesions induced by captopril. Egypt. J. Histol., 18(1): 209-219.

Saleh, F. (1990): Metabolic effects of carbamate insecticide (methomyl) on rats. 11-Change in some blood biochemical indices in rats poison with the insecticide. Egypt. J. Physiol. Sci. 14: 65-74.

Smit, A.J.; Vander-Laans, S.; Monachy, J.; Kallenberg, C.G. and Donker, A.J. (1984): Cutaneous reactions to captopril. Clin. Allergy, 14: 413-419.

Sokal, R.R. and Rahif, F. J. (1981): Biometry: The principles and practice of statistics in biological research. $2^{\text {nd }}$ ed. Freeman, W.H. Company. San. Francisco.

Sort, P.; Mas, A.; Salmeron, J.M.; Braguera, M. and Rodes, J. (1996): Recurrent liver involvement in heat stroke. liver. 16(5): 335-337.

Swales, J. (1995): Renal dysfunction in essential hypertension. Lancet, 345:740.

Taguma, Y.; Kitamoto, Y.; Futaki, G.; Ueda, H.; Monma, H.; Ishizaki, M. et al. (1985): Effect of captopril on heavy proteinuria in azomtic diabetics. N. Engle. J. Med. 313: 1617-1620.

Urata H., Kinoshita A., Misono KS, Bumpus FM, and Husain A: Identification of a highly specific chymase as the major angiotensin IIforming enzyme in the heart. J. Biol. chem. 1990, 265: 22348-22357.

Urata H., Kinoshita, A., Perez DM., Misono Ks, Bumpus FM. and Graham RM, (1991): Cloning of the gen cDNA for human heart chymas. J. Biol. chem., 266: 17173-17179.

Vargas, A.V.; Robinson, A.V. and Schulak, J.A. (1994): Captopril a melioration of renal reperfusion injury. J. Surg. Res., 57(1): 28-32. 
Vernigora, A.N.; Gengin, M.T.; Nikishin, N.N. and shchetinina, N.V. (1996): Effect of captopril on angiotensin-converting enzyme activity and animal behavior in the "open field" test. Vopr. Med. Khim., 42(1): 34-38.

Westra, A. and Dewey, W.C. (1971): Variation in the sensitivity to heat shock during the cell cycle of the Chinese hamster cell in vitro. Int. J. Raidat. Bio., 19: 467-477-24.

Zats, R. Dunn, B.R.; Meyer, T.W.;
Anderson, S.; Rennke, H.G. and Brenner, B.M. (1986): Prevention of diabetic glomerulopathy by pharmacological a melioration of glomerular hypertension. J. Clin. Invest. 77: 1925-1930.

Zhang, Y.H. and XU, S.C. (1994): Captopril cardioplegia myocardial protection in the hypertrophied rat hearts. Int. J. Cardiol. 47(2): 131-177.

Table (1): Show the percentage of body weight changes under the effect of heat stress and captopril (0.7 and $1.4 \mathrm{mg} / \mathrm{kg}$. b.wt) organ/body weight in male albino rats.

\begin{tabular}{|c|c|c|c|c|c|c|c|c|c|}
\hline \multirow{2}{*}{\multicolumn{2}{|c|}{ Organs }} & \multicolumn{4}{|c|}{ Treated period (10 days) } & \multicolumn{4}{|c|}{ Recovery period (10 days) } \\
\hline & & $\begin{array}{c}\text { Contr } \\
\text { ol }\end{array}$ & $\begin{array}{l}\text { Heat } \\
\text { stress }\end{array}$ & $\begin{array}{c}\text { heat } \\
\text { stess } \\
+ \\
\text { low } \\
\text { dose } \\
\end{array}$ & $\begin{array}{c}\text { heat } \\
\text { stess } \\
+ \\
\text { high } \\
\text { dose }\end{array}$ & $\begin{array}{c}\text { Contr } \\
\text { ol }\end{array}$ & $\begin{array}{l}\text { Heat } \\
\text { stress }\end{array}$ & $\begin{array}{c}\text { heat } \\
\text { stess } \\
+ \\
\text { low } \\
\text { dose }\end{array}$ & $\begin{array}{c}\text { heat } \\
\text { stess } \\
+ \\
\text { high } \\
\text { dose }\end{array}$ \\
\hline Liver & $\begin{array}{c}\text { Mean } \\
\pm \text { S.E } \\
\text { Probabil } \\
\quad \text { ity } \\
\end{array}$ & $\begin{array}{l}4.92 \\
0.10\end{array}$ & $\begin{array}{l}4.90 \\
0.28\end{array}$ & $\begin{array}{r}4.40 \\
0.29 \\
\text { insig. }\end{array}$ & $\begin{array}{l}4.42 \\
0.21 \\
\text { insig. }\end{array}$ & $\begin{array}{l}4.88 \\
0.13\end{array}$ & $\begin{array}{r}4.74 \\
0.12 \\
\text { insig. }\end{array}$ & $\begin{array}{r}4.60 \\
0.14 \\
\text { insig. }\end{array}$ & $\begin{array}{r}4.78 \\
0.06 \\
\text { insig. }\end{array}$ \\
\hline kidney & $\begin{array}{c}\text { Mean } \\
\pm S . E \\
\text { Probabil } \\
\quad \text { ity } \\
\end{array}$ & $\begin{array}{l}0.76 \\
0.02\end{array}$ & $\begin{array}{l}0.74 \\
0.02\end{array}$ & $\begin{array}{c}0.72 \\
0.04 \\
\text { insig. }\end{array}$ & $\begin{array}{l}0.74 \\
0.02 \\
\text { insig. }\end{array}$ & $\begin{array}{l}0.76 \\
0.04\end{array}$ & $\begin{array}{r}0.86 \\
0.24 \\
\text { insig. }\end{array}$ & $\begin{array}{c}0.72 \\
0.04 \\
\text { insig. }\end{array}$ & $\begin{array}{r}0.78 \\
0.04 \\
\text { insig. }\end{array}$ \\
\hline Heart & $\begin{array}{c}\text { Mean } \\
\pm \text { S.E } \\
\text { Probabil } \\
\quad \text { ity }\end{array}$ & $\begin{array}{l}0.46 \\
0.02\end{array}$ & $\begin{array}{l}0.64 \\
0.02\end{array}$ & $\begin{array}{c}0.56 \\
0.02 \\
< \\
0.01\end{array}$ & $\begin{array}{c}0.44 \\
0.02 \\
< \\
0.01\end{array}$ & $\begin{array}{l}0.52 \\
0.04\end{array}$ & $\begin{array}{l}0.50 \\
0.03 \\
\text { insig. }\end{array}$ & $\begin{array}{r}0.50 \\
0.03 \\
\text { insig. }\end{array}$ & $\begin{array}{r}0.46 \\
0.02 \\
\text { insig. }\end{array}$ \\
\hline brain & $\begin{array}{c}\text { Mean } \\
\pm S . E \\
\text { Probabil } \\
\quad \text { ity }\end{array}$ & $\begin{array}{l}0.88 \\
0.03\end{array}$ & $\begin{array}{l}0.86 \\
0.02\end{array}$ & $\begin{array}{r}1.04 \\
0.07 \\
\text { insig. }\end{array}$ & $\begin{array}{l}0.98 \\
0.04 \\
\text { insig. }\end{array}$ & $\begin{array}{l}0.82 \\
0.04\end{array}$ & $\begin{array}{c}0.83 \\
0.02 \\
\text { insig. }\end{array}$ & $\begin{array}{r}0.88 \\
0.07 \\
\text { insig. }\end{array}$ & $\begin{array}{r}0.88 \\
0.02 \\
\text { insig. }\end{array}$ \\
\hline Testes & $\begin{array}{c}\text { Mean } \\
\pm S . E \\
\text { Probabil } \\
\quad \text { ity }\end{array}$ & $\begin{array}{l}1.54 \\
0.04\end{array}$ & $\begin{array}{l}1.58 \\
0.03\end{array}$ & $\begin{array}{r}1.70 \\
0.07 \\
\text { insig. }\end{array}$ & $\begin{array}{l}1.62 \\
0.06 \\
\text { insig. }\end{array}$ & $\begin{array}{l}1.56 \\
0.04\end{array}$ & $\begin{array}{c}1.54 \\
0.02 \\
-\end{array}$ & $\begin{array}{c}1.72 \\
0.04 \\
-\end{array}$ & $\begin{array}{c}1.74 \\
0.04 \\
-\end{array}$ \\
\hline spleen & $\begin{array}{c}\text { Mean } \\
\pm \text { S.E } \\
\text { Probabil }\end{array}$ & $\begin{array}{l}0.32 \\
0.03\end{array}$ & $\begin{array}{l}0.58 \\
0.02\end{array}$ & $\begin{array}{c}0.48 \\
0.04 \\
< \\
0.01\end{array}$ & $\begin{array}{c}0.52 \\
0.04 \\
< \\
0.01\end{array}$ & $\begin{array}{l}0.36 \\
0.02\end{array}$ & $\begin{array}{c}0.30 \\
0.03 \\
\text { insig. }\end{array}$ & $\begin{array}{c}0.42 \\
0.04 \\
\text { insig. }\end{array}$ & $\begin{array}{c}0.40 \\
0.03 \\
\text { insig. }\end{array}$ \\
\hline
\end{tabular}




\begin{tabular}{|l|l|l|l|l|l|l|l|l|l|}
\hline & ity & & & & & & & & \\
\hline
\end{tabular}

Table (2): Effect of heat stress and captopril (0.7 and $1.4 \mathrm{mg} / \mathrm{kg} . \mathrm{b} . \mathrm{wt})$ on total protein ( $\mathrm{mg} / \mathrm{g}$ tissue) of liver, heart, kidney, muscle and brain of male albino rats.

\begin{tabular}{|c|c|c|c|c|c|c|c|c|c|}
\hline \multirow{2}{*}{\multicolumn{2}{|c|}{ Organ Parameters }} & \multicolumn{4}{|c|}{ Treated period (10 days) } & \multicolumn{4}{|c|}{ Recovery period ( 10 days) } \\
\hline & & Control & $\begin{array}{l}\text { Heat } \\
\text { stress }\end{array}$ & $\begin{array}{c}\text { heat } \\
\text { stess } \\
+ \\
\text { low } \\
\text { dose } \\
\end{array}$ & $\begin{array}{c}\text { heat } \\
\text { stess } \\
+ \\
\text { high } \\
\text { dose } \\
\end{array}$ & Control & $\begin{array}{l}\text { Heat } \\
\text { stress }\end{array}$ & $\begin{array}{c}\text { heat } \\
\text { stess } \\
+ \\
\text { low } \\
\text { dose } \\
\end{array}$ & $\begin{array}{c}\text { heat } \\
\text { stess } \\
+ \\
\text { high } \\
\text { dose } \\
\end{array}$ \\
\hline Liver & $\begin{array}{c}\text { Mean } \\
\pm \text { S.E } \\
\text { Probability }\end{array}$ & $\begin{array}{c}69.0 \\
0.9\end{array}$ & $\begin{array}{c}62.0 \\
0.8 \\
<0.01 \\
\end{array}$ & $\begin{array}{c}60.0 \\
0.4 \\
<0.01 \\
\end{array}$ & $\begin{array}{c}55.0 \\
0.6 \\
<0.01 \\
\end{array}$ & $\begin{array}{c}67.0 \\
2.1\end{array}$ & $\begin{aligned} & 61.5 \\
& 2 \\
&< \\
&<0.01\end{aligned}$ & $\begin{array}{c}61.0 \\
1.4 \\
<0.05 \\
\end{array}$ & $\begin{array}{c}55.0 \\
1.2 \\
<0.01 \\
\end{array}$ \\
\hline Heart & $\begin{array}{c}\text { Mean } \\
\pm \text { S.E } \\
\text { Probability }\end{array}$ & $\begin{array}{c}21.0 \\
0.5\end{array}$ & $\begin{array}{c}18.3 \\
0.4 \\
<0.05\end{array}$ & $\begin{array}{c}18.0 \\
0.3 \\
<0.01\end{array}$ & $\begin{array}{c}16.1 \\
0.2 \\
<0.01\end{array}$ & $\begin{array}{c}20.0 \\
0.6\end{array}$ & $\begin{array}{l}18.0 \\
0.4 \\
<0.05\end{array}$ & $\begin{array}{c}18.1 \\
0.5 \\
<0.05\end{array}$ & $\begin{array}{c}14.2 \\
0.6 \\
<0.01\end{array}$ \\
\hline Kidney & $\begin{array}{c}\text { Mean } \\
\pm \text { S.E } \\
\text { Probability }\end{array}$ & $\begin{array}{c}19.2 \\
0.4\end{array}$ & $\begin{array}{c}17.1 \\
0.3 \\
<0.01\end{array}$ & $\begin{array}{c}16.0 \\
0.3 \\
<0.01\end{array}$ & $\begin{array}{c}14.0 \\
0.4 \\
<0.01\end{array}$ & $\begin{array}{c}18.5 \\
0.8\end{array}$ & $\begin{array}{c}16.5 \\
0.5 \\
-\end{array}$ & $\begin{array}{c}16.0 \\
0.4 \\
-\end{array}$ & $\begin{array}{c}14.0 \\
0.7 \\
<0.05\end{array}$ \\
\hline Muscle & $\begin{array}{c}\text { Mean } \\
\pm \text { S.E } \\
\text { Probability }\end{array}$ & $\begin{array}{c}26.5 \\
1.9\end{array}$ & $\begin{array}{c}22.5 \\
1.2 \\
-\end{array}$ & $\begin{array}{c}20.5 \\
0.6 \\
-\end{array}$ & $\begin{array}{c}20.0 \\
0.5 \\
-\end{array}$ & $\begin{array}{c}24.0 \\
1.2\end{array}$ & $\begin{array}{c}20.8 \\
1.4 \\
-\end{array}$ & $\begin{array}{c}20.0 \\
0.6 \\
-\end{array}$ & $\begin{array}{c}18.0 \\
0.7 \\
-\end{array}$ \\
\hline Brain & $\begin{array}{c}\text { Mean } \\
\pm \text { S.E } \\
\text { Probability }\end{array}$ & $\begin{array}{c}18.0 \\
0.9\end{array}$ & $\begin{array}{c}16.0 \\
1.1 \\
-\end{array}$ & $\begin{array}{c}14.0 \\
0.8 \\
-\end{array}$ & $\begin{array}{c}15.0 \\
0.7 \\
-\end{array}$ & $\begin{array}{c}18.0 \\
0.8\end{array}$ & $\begin{array}{c}16.0 \\
0.4 \\
-\end{array}$ & $\begin{array}{c}16.0 \\
0.5 \\
-\end{array}$ & $\begin{array}{c}15.0 \\
0.4 \\
-\end{array}$ \\
\hline
\end{tabular}

Table (3): Effect of heat stress and captopril (0.7 and $1.4 \mathrm{mg} / \mathrm{kg} . \mathrm{b} . \mathrm{wt}$ ) on total lipids ( $\mathrm{mg} / \mathrm{g}$ tissue) of liver, heart, kidney, muscle and brain of male albino rats.

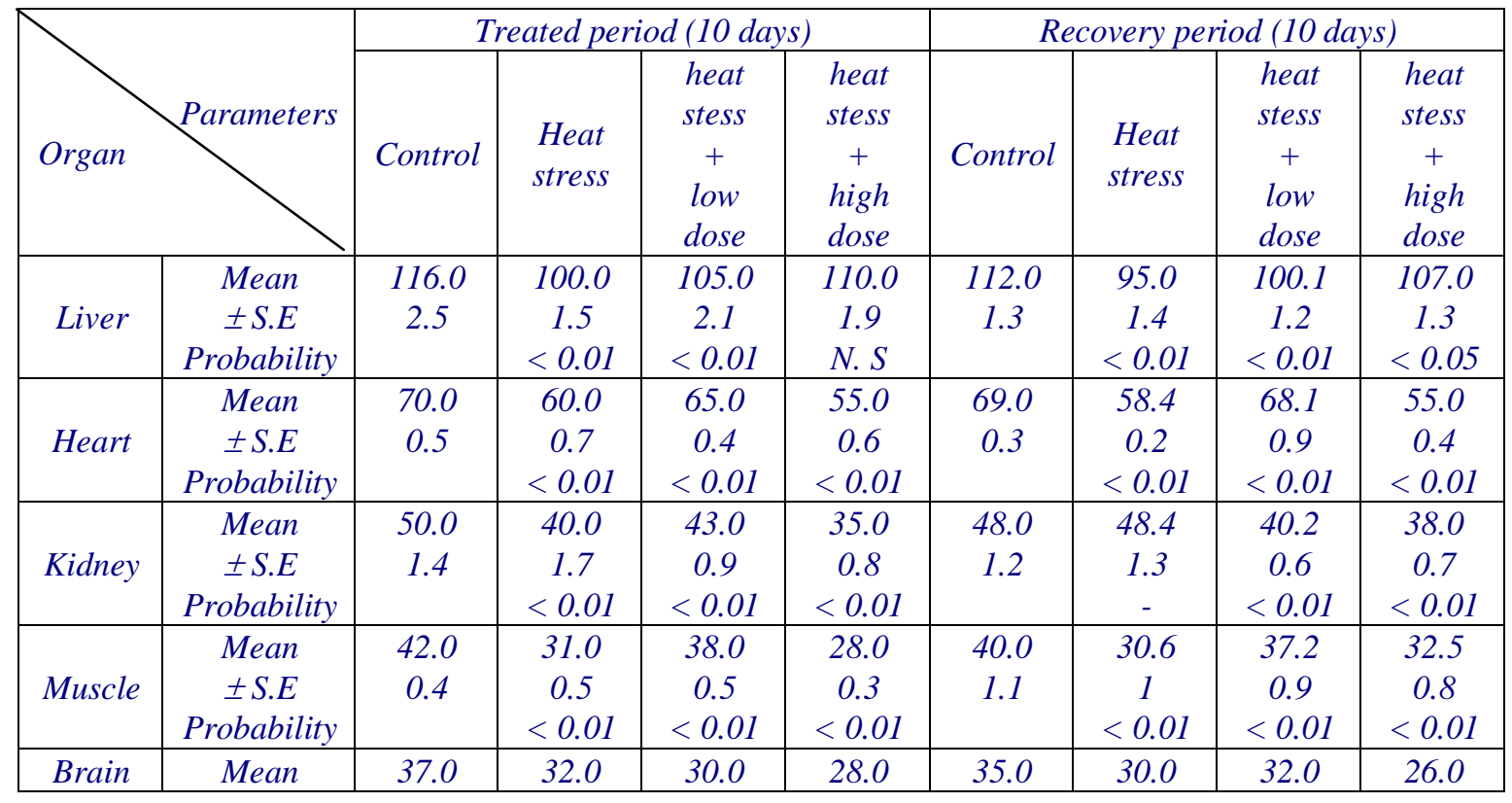




\begin{tabular}{|c|c|c|c|c|c|c|c|c|c|}
\hline & $\begin{array}{c} \pm \text { S.E } \\
\text { Probability }\end{array}$ & 0.9 & $\begin{array}{c}0.8 \\
<0.01\end{array}$ & $\begin{array}{c}0.2 \\
<0.01\end{array}$ & $\begin{array}{c}0.4 \\
<0.01\end{array}$ & 0.4 & $\begin{array}{c}0.6 \\
<0.01\end{array}$ & $\begin{array}{c}0.8 \\
<0.01\end{array}$ & $\begin{array}{c}0.3 \\
<0.01\end{array}$ \\
\hline
\end{tabular}

Table (4): Effect of heat stress and captopril (0.7 and $1.4 \mathrm{mg} / \mathrm{kg} . \mathrm{b} . \mathrm{wt})$ on total cholesterol ( $\mathrm{mg} / \mathrm{g}$ tissue) of liver, heart, kidney, muscle and brain of male albino rats.

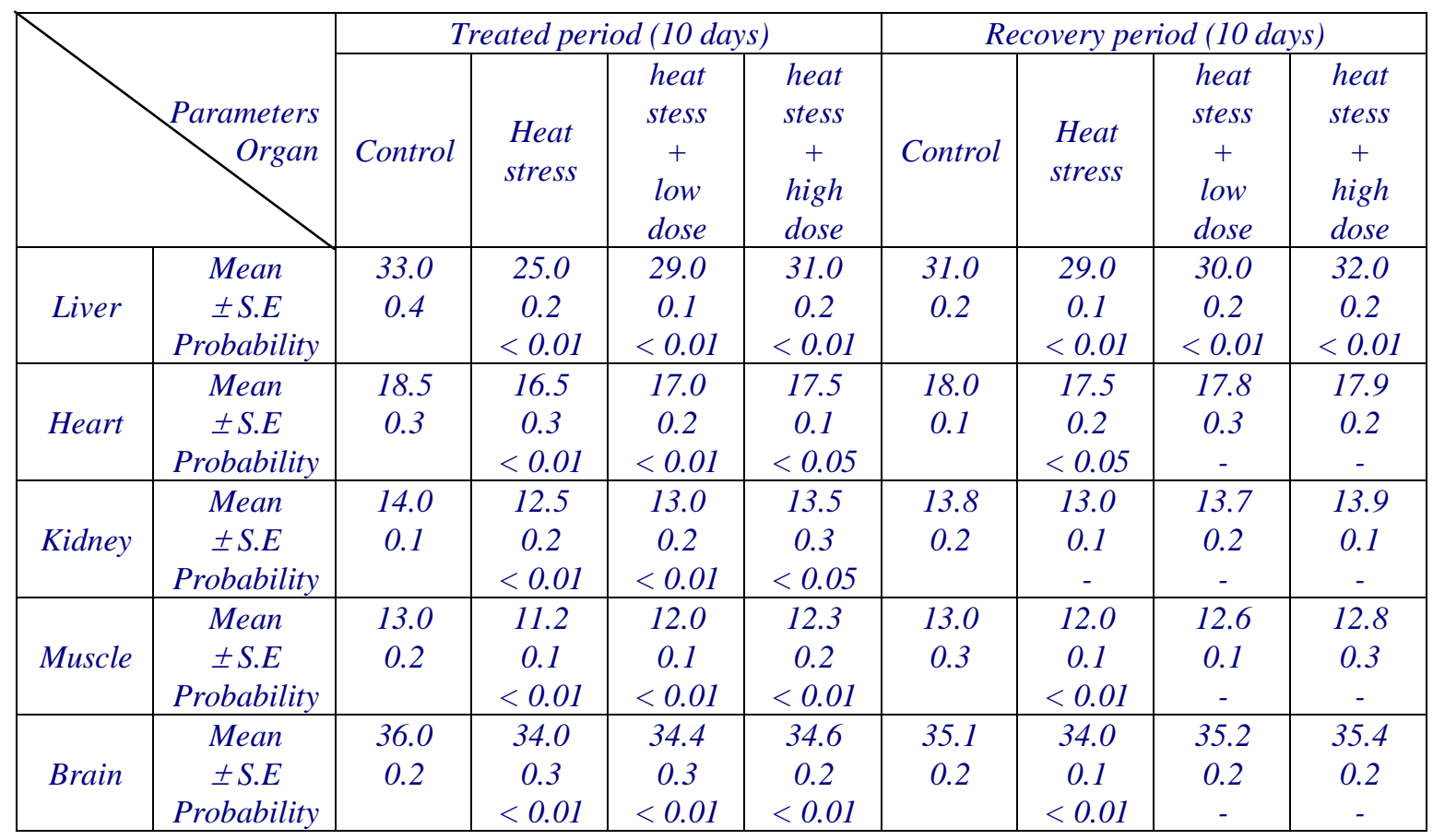

Table (5): Effect of heat stress and captopril ( 0.7 and $1.4 \mathrm{mg} / \mathrm{kg} . \mathrm{b} . \mathrm{wt})$ on AST activity (u/g tissue) of liver, heart, kidney, muscle and brain of albino rats.

\begin{tabular}{|c|c|c|c|c|c|c|c|c|c|}
\hline & \multicolumn{4}{|c|}{ Treated (10 days) } & \multicolumn{4}{|c|}{ Recovery (10 days) } \\
\hline & & Control & $\begin{array}{l}\text { Heat } \\
\text { stress }\end{array}$ & $\begin{array}{c}\text { heat } \\
\text { stess } \\
+ \\
\text { low } \\
\text { dose } \\
\end{array}$ & $\begin{array}{c}\text { Heat } \\
\text { stess } \\
+ \\
\text { high } \\
\text { dose }\end{array}$ & Control & $\begin{array}{l}\text { Heat } \\
\text { stress }\end{array}$ & $\begin{array}{c}\text { heat } \\
\text { stess } \\
+ \\
\text { low } \\
\text { dose }\end{array}$ & $\begin{array}{c}\text { heat } \\
\text { stess } \\
+ \\
\text { high } \\
\text { dose }\end{array}$ \\
\hline \multirow{2}{*}{ Liver } & Mean & 19.1 & 23.0 & 22.0 & 21.0 & 20.1 & 22.5 & 21.5 & 21.0 \\
\hline & \pm S.E & 0.3 & 0.3 & 0.5 & 0.2 & 0.3 & 0.4 & 0.2 & 0.3 \\
\hline \multirow{2}{*}{ Heart } & Mean & 22.0 & 24.0 & 23.0 & 23.0 & 21.0 & 23.0 & 21.5 & 21.2 \\
\hline & $\pm S . E$ & 0.3 & 0.4 & 0.2 & 0.3 & 0.4 & 0.2 & 0.3 & 0.2 \\
\hline \multirow{2}{*}{ Kidney } & Mean & 17.1 & 20.1 & 19.5 & 18.5 & 16.8 & 19.5 & 18.5 & 18.0 \\
\hline & $\pm S . E$ & 0.2 & 0.3 & 0.2 & 0.4 & 0.2 & 0.3 & 0.4 & 0.2 \\
\hline \multirow{2}{*}{ Muscle } & Mean & 19.5 & 22.0 & 22.0 & 21.9 & 19.1 & 22.0 & 21.8 & 20.5 \\
\hline & \pm S.E & 0.2 & 0.3 & 0.3 & 0.2 & 0.4 & 0.2 & 0.3 & 0.3 \\
\hline \multirow{2}{*}{ Brain } & Mean & 15.0 & 17.1 & 17.0 & 16.5 & 15.5 & 16.8 & 16.5 & 15.5 \\
\hline & $\pm S . E$ & 0.3 & 0.4 & 0.2 & 0.3 & 0.3 & 0.3 & 0.2 & 0.4 \\
\hline
\end{tabular}


Eman G.E. Helal et al

Table (6): Effect of heat stress and captopril $(0.7$ and $1.4 \mathrm{mg} / \mathrm{kg}$.

b.wt) on ALT activity (u/g tissue) of liver, heart, kidney, muscle and brain of male albino rats.

\begin{tabular}{|c|c|c|c|c|c|c|c|c|c|}
\hline \multirow{2}{*}{\multicolumn{2}{|c|}{ Parameters }} & \multicolumn{4}{|c|}{ Treated period (10 days) } & \multicolumn{4}{|c|}{ Recovery period (10 days) } \\
\hline & & Control & $\begin{array}{l}\text { Heat } \\
\text { stress }\end{array}$ & $\begin{array}{c}\text { heat } \\
\text { stess } \\
+ \\
\text { low } \\
\text { dose }\end{array}$ & $\begin{array}{c}\text { heat } \\
\text { stess } \\
+ \\
\text { high } \\
\text { dose }\end{array}$ & $\begin{array}{c}\text { Contr } \\
\text { ol }\end{array}$ & $\begin{array}{l}\text { Heat } \\
\text { stress }\end{array}$ & $\begin{array}{c}\text { heat } \\
\text { stess } \\
+ \\
\text { low } \\
\text { dose }\end{array}$ & $\begin{array}{c}\text { heat } \\
\text { stess } \\
+ \\
\text { high } \\
\text { dose }\end{array}$ \\
\hline Liver & $\begin{array}{l}\text { Mean } \\
\pm \text { S.E }\end{array}$ & $\begin{array}{c}23.0 \\
0.2\end{array}$ & $\begin{array}{c}17.5 \\
0.3\end{array}$ & $\begin{array}{c}15.0 \\
0.4\end{array}$ & $\begin{array}{c}14.5 \\
0.2\end{array}$ & $\begin{array}{c}24.0 \\
0.1\end{array}$ & $\begin{array}{c}16.2 \\
0.3\end{array}$ & $\begin{array}{c}14.0 \\
0.2\end{array}$ & $\begin{array}{r}13.5 \\
0.2\end{array}$ \\
\hline Heart & $\begin{array}{l}\text { Mean } \\
\pm \text { S.E }\end{array}$ & $\begin{array}{c}19.5 \\
0.4\end{array}$ & $\begin{array}{l}22 \\
0.2\end{array}$ & $\begin{array}{c}23.0 \\
0.3\end{array}$ & $\begin{array}{c}22.8 \\
0.1\end{array}$ & $\begin{array}{c}19.0 \\
0.3\end{array}$ & $\begin{array}{c}22.5 \\
0.2\end{array}$ & $\begin{array}{r}21.2 \\
0.2\end{array}$ & $\begin{array}{c}20.0 \\
0.2\end{array}$ \\
\hline Kidney & $\begin{array}{l}\text { Mean } \\
\pm \text { S.E }\end{array}$ & $\begin{array}{c}16.4 \\
0.2\end{array}$ & $\begin{array}{c}20.5 \\
0.3\end{array}$ & $\begin{array}{c}19.5 \\
0.3\end{array}$ & $\begin{array}{c}18.5 \\
0.4\end{array}$ & $\begin{array}{c}16.0 \\
0.3\end{array}$ & $\begin{array}{c}18.0 \\
0.2\end{array}$ & $\begin{array}{c}17.2 \\
0.2\end{array}$ & $\begin{array}{r}17.8 \\
0.3\end{array}$ \\
\hline Muscle & $\begin{array}{l}\text { Mean } \\
\pm \text { S.E }\end{array}$ & $\begin{array}{c}20.5 \\
0.3\end{array}$ & $\begin{array}{c}23.2 \\
0.4\end{array}$ & $\begin{array}{c}22.5 \\
0.3\end{array}$ & $\begin{array}{l}22 \\
0.1\end{array}$ & $\begin{array}{c}19.5 \\
0.3\end{array}$ & $\begin{array}{c}21.5 \\
0.2\end{array}$ & $\begin{array}{c}21.0 \\
0.3\end{array}$ & $\begin{array}{c}20.0 \\
0.4\end{array}$ \\
\hline Brain & $\begin{array}{l}\text { Mean } \\
\pm \text { S.E }\end{array}$ & $\begin{array}{c}21.8 \\
0.4\end{array}$ & $\begin{array}{c}25.0 \\
0.3\end{array}$ & $\begin{array}{c}23.0 \\
0.3\end{array}$ & $\begin{array}{r}22.8 \\
0.4\end{array}$ & $\begin{array}{c}20.8 \\
0.3\end{array}$ & $\begin{array}{c}22.4 \\
0.2\end{array}$ & $\begin{array}{c}21.8 \\
0.3\end{array}$ & $\begin{array}{c}21.0 \\
0.4\end{array}$ \\
\hline
\end{tabular}


The Interaction Between Angiotensin Converting

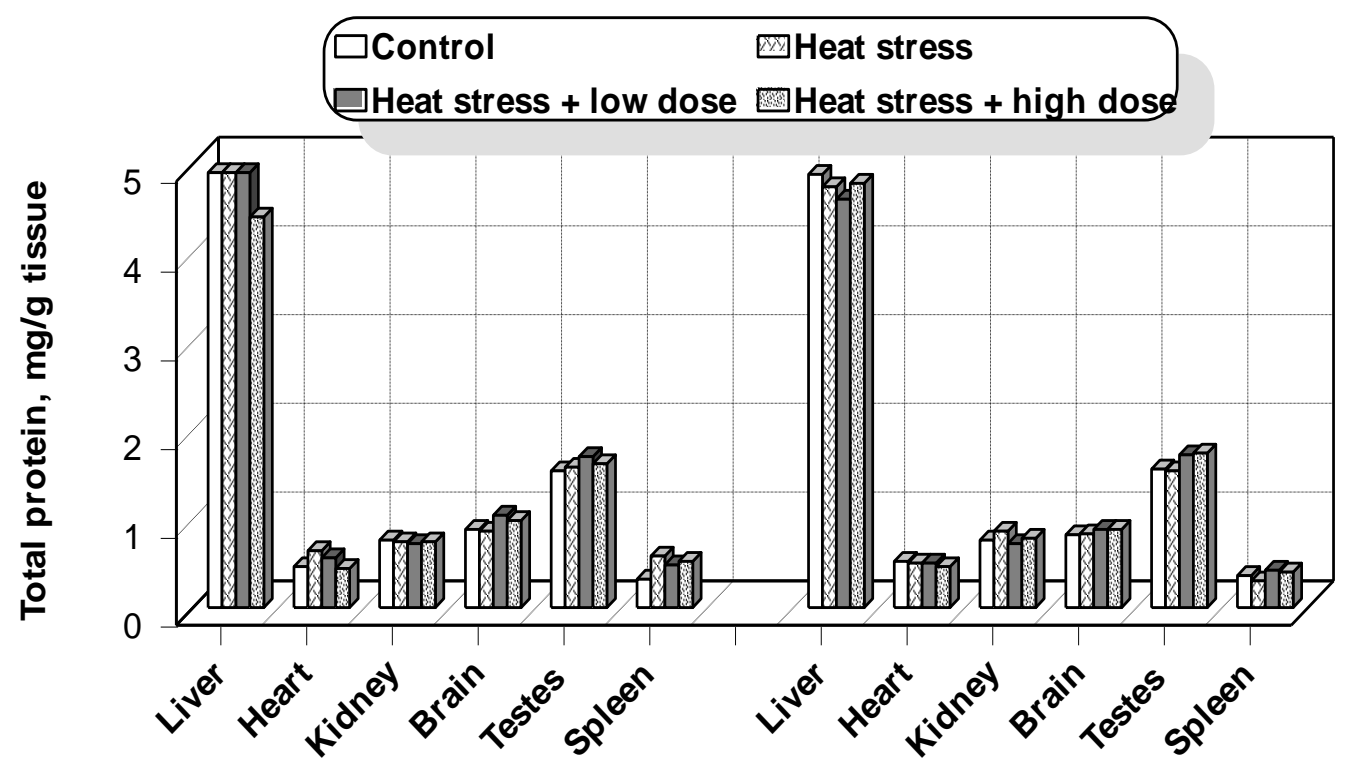

Fig. (1): Digramatic representation show the percentage of organs/body weight changes under the effect of heat stress and captopirol ( 0.7 and $1.4 \mathrm{mg} / \mathrm{g} \mathrm{b}$. wt. ) in malevalbino rats.

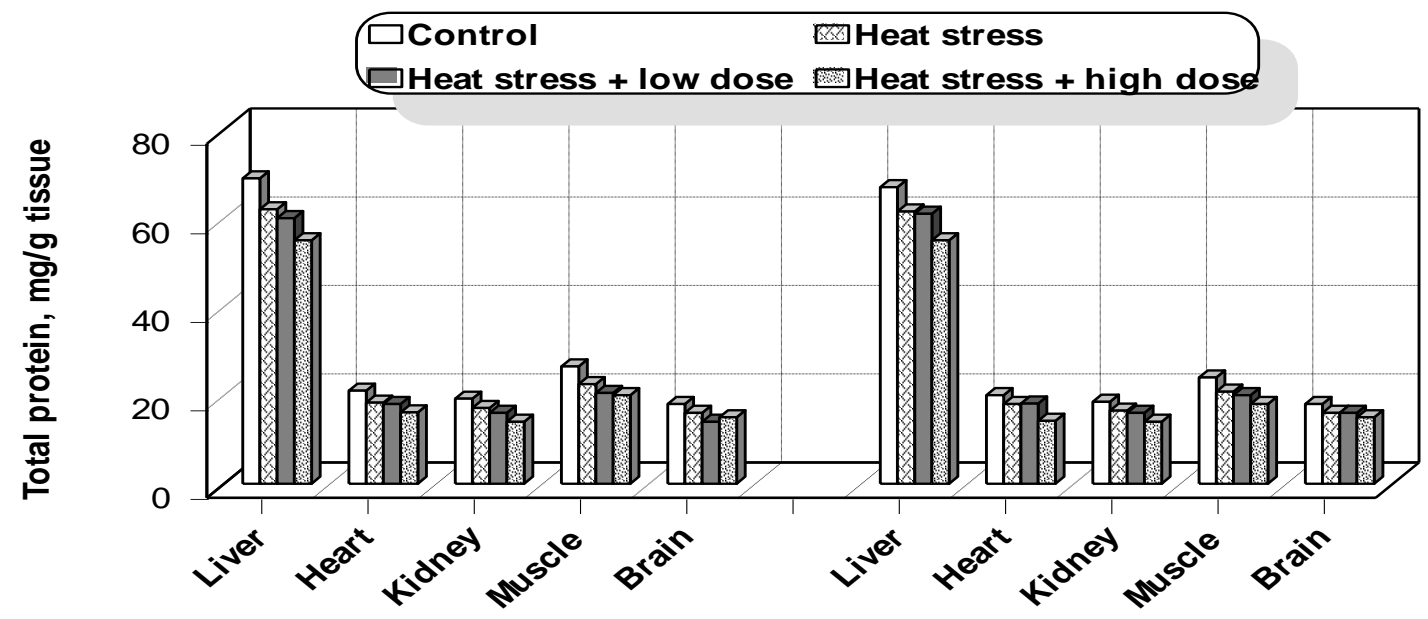

Fig. (2): Digramatic representation show the effect of heat stress and captopirol (0.7 and $1.4 \mathrm{mg} / \mathrm{g} \mathrm{b}$. wt. ) on total protein of some organs after treatment and recovery period. 


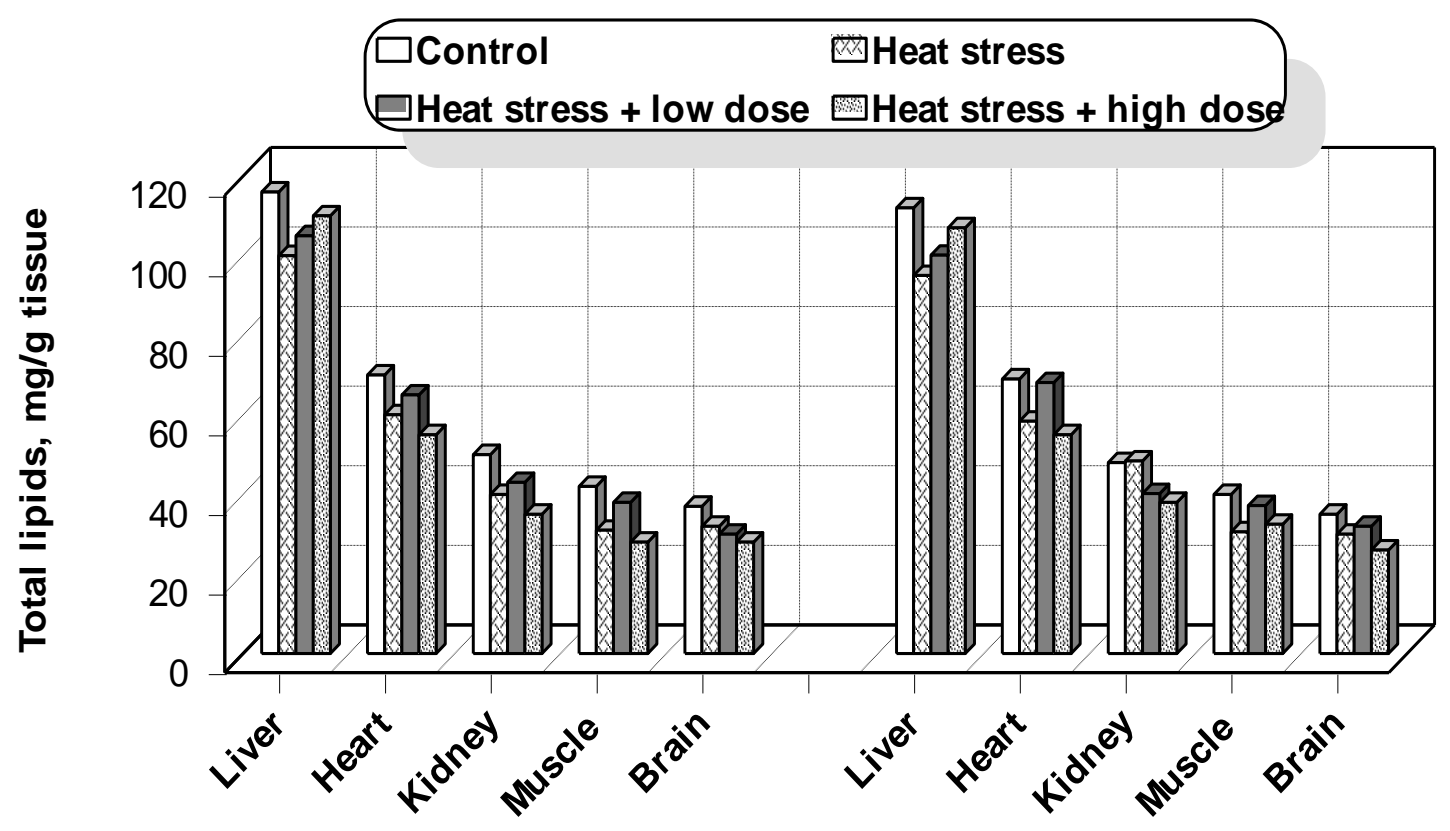

Fig. (3): Digramatic representation show the effect of heat stress and captopirol (0.7 and $1.4 \mathrm{mg} / \mathrm{g} \mathrm{b}$. wt. ) on total lipids of some organs after treatment and recovery period.

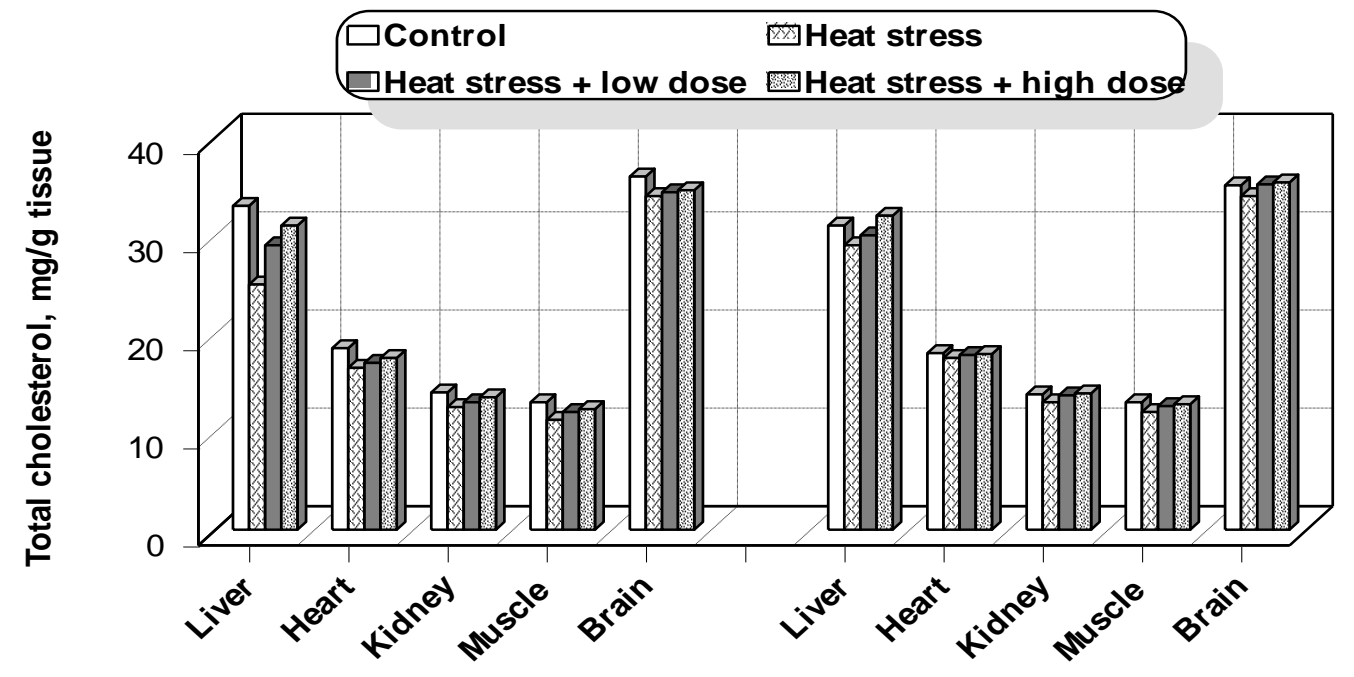

Fig. (4): Digramatic representation show the effect of heat stress and captopirol ( 0.7 and $1.4 \mathrm{mg} / \mathrm{g}$ b. wt. ) on total cholesterol of some organs after treatment and recovery period. 
The Interaction Between Angiotensin Converting

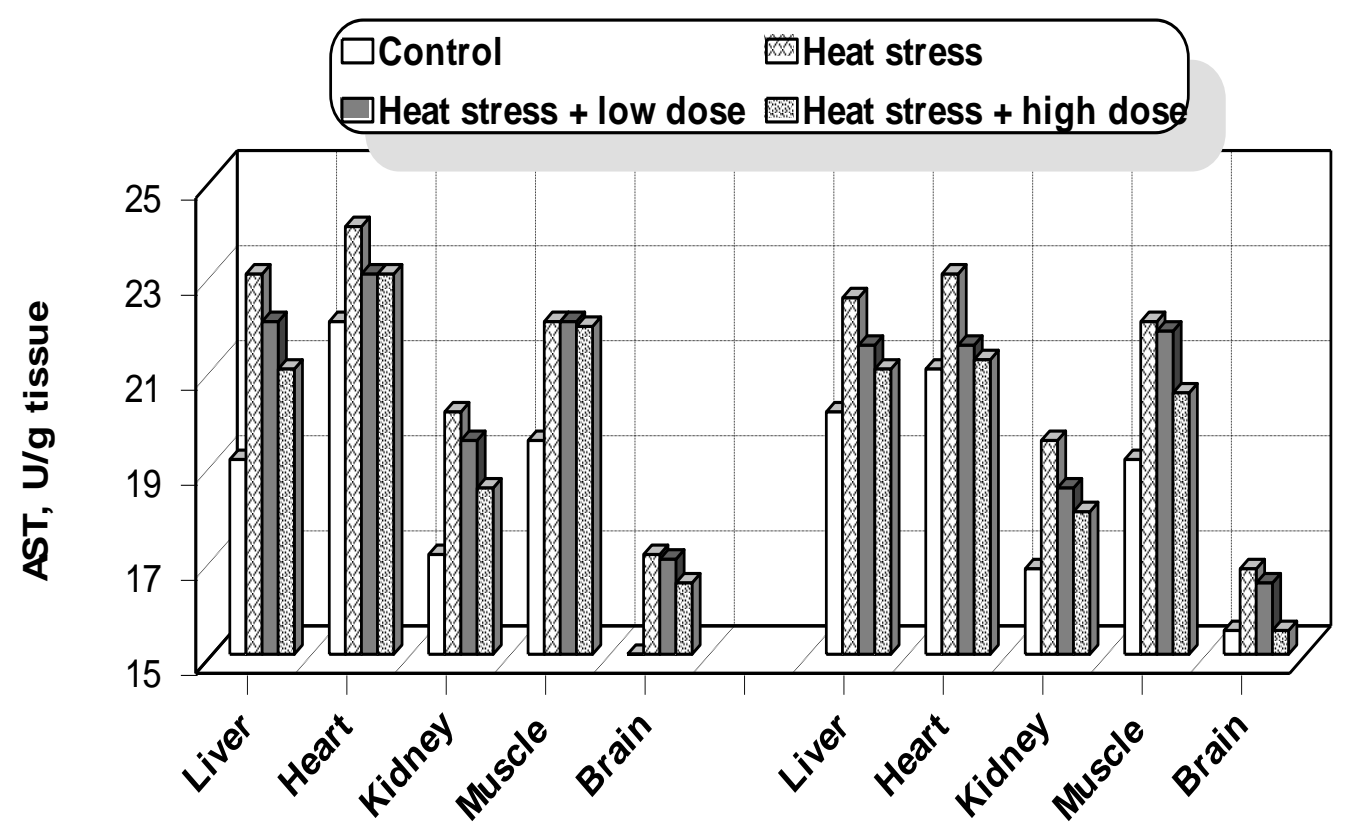

Fig. (5): Digramatic representation show the effect of heat stress and captopirol ( 0.7 and $1.4 \mathrm{mg} / \mathrm{g} \mathrm{b}$. wt.) on AST of some organs after treatment and recovery period.

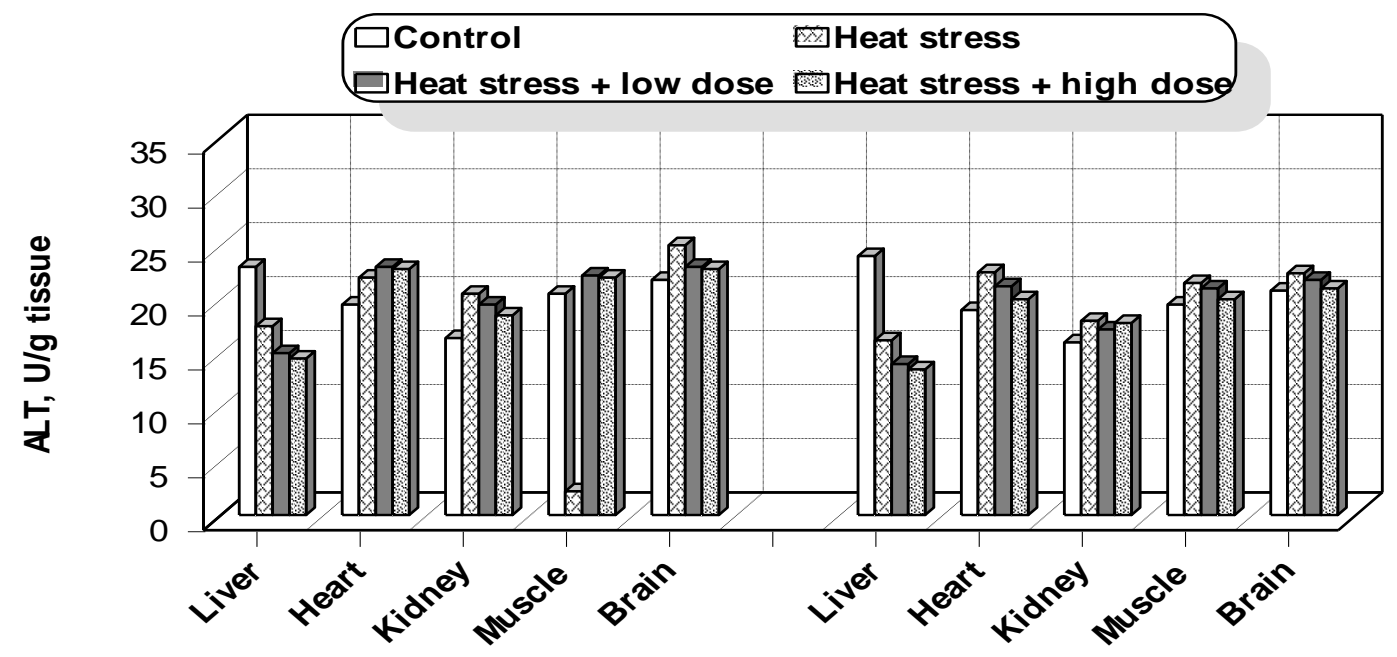

Fig. (6): Digramatic representation show the effect of heat stress and captopirol ( 0.7 and $1.4 \mathrm{mg} / \mathrm{g}$ b. wt.) on ALT of some organs after treatment and recovery period. 


\section{التفاعل بين مثبط الأنزيم المحول \\ للإنجيوتنسين (الكابتوبريل) وتأثير إرتفاع درجة الحرارة}

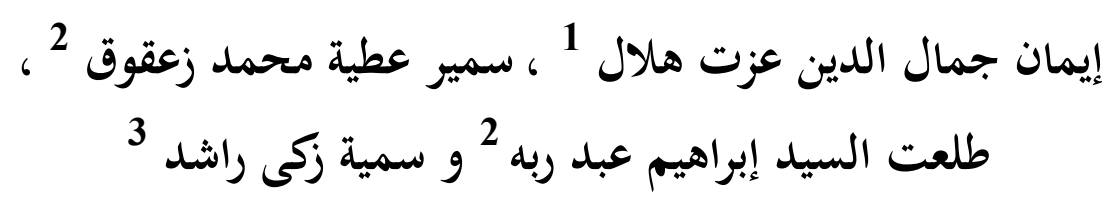

$$
\begin{aligned}
& 1 \text { قسم علم الحيون - كلية العلوم - جامعة الأزهر فرع البنات - ملدينة نصر- القاهرة } \\
& 1 \text { قسم علم الحيوان - كلية العلوم - جامعة الأزهر - مدينة نصر - القاهرة }
\end{aligned}
$$

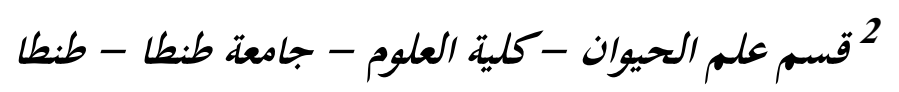

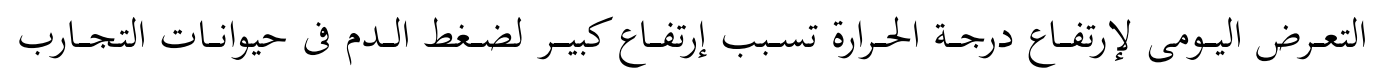

(الفئران البيضاء). وأنه معروف أن نظام الرنين - البخيوتنسين نشط خهلال تنظيم إرتفاع درجـة الحسرارة.

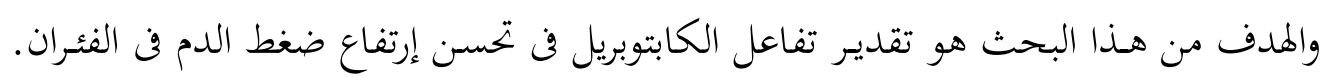
قسمت الحيوانات إلى أربع بحموعات وعوملت كالآتى :

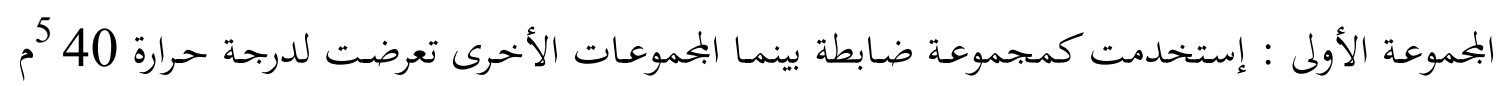

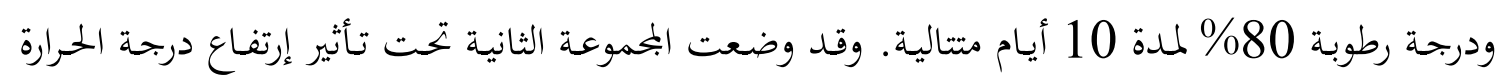

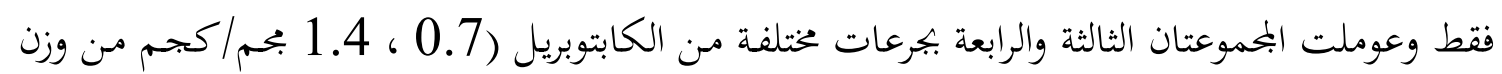

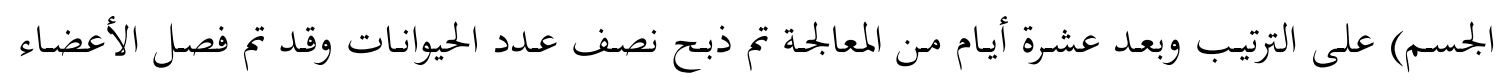

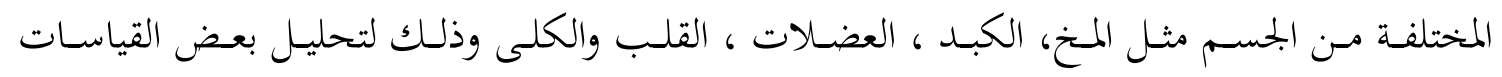

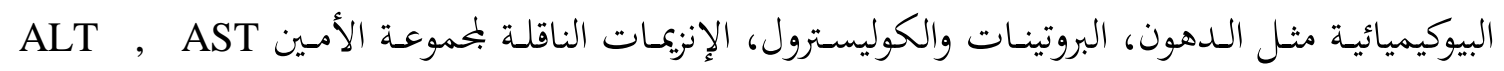

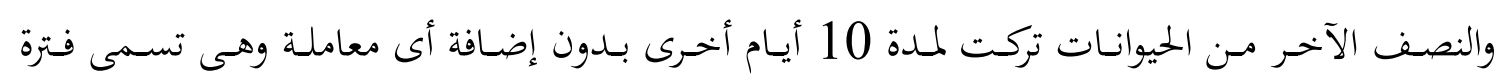
الإستشفاء.

وقد أوضحت النتائج إنخفاض ملحوظ فن البروتين الكلى للكبد، القلب ، الكلى والدهون الكلية

$$
\text { لكل من القلب ، العضلات والمخ والكوليسترول الكلى للكبد. }
$$

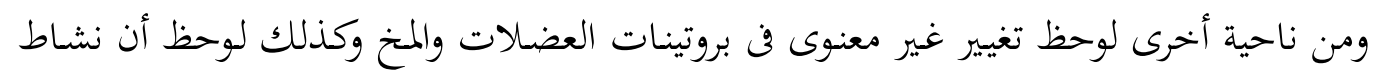

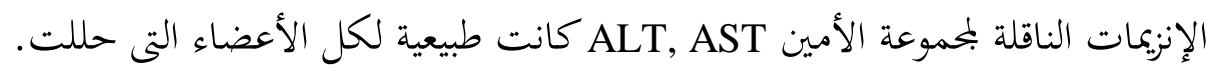

